\title{
Peran Mediasi Thriving at Work pada Pengaruh Proactive Personality terhadap Career Adaptability
}

\author{
Muhammad Agung Prasetyo Wibowo \\ Universitas Airlangga \\ IBG Adi Permana \\ Universitas Airlangga \\ (ibg.adipermana@gmail.com)
}

\begin{abstract}
Career adaptability is one of the resource that must be possessed by every person on this day, because it has been considered as a driving factor that help people to achieve the desired work goals. Moreover, nowadays it has been known that the work arrangements are unpredictable and too many changes that occurs, because it is considered to have no boundaries and transparent, one of them is the emergence of new job relationships such as internet freelance. Antacedents that have been known previously from career adaptability are widely known as proactive personality, then This study also discuss another antecedent for career adaptability, which is known as thriving at work. This study also confirms previous research that discuss the mediating role of thriving at work on the effect of proactive personality on career adaptability. Total of the sample on this study are 352 internet freelancers from an online employement platform in Indonesia, where the internet freelance responded to the questionnaire that was shared by the author through an online approach. The obtained data have been analyzed by conducting a simple regression test equipped with PROCESS Model 4. Result have shown that there is a significant direct relationship of the three variables raised in this study, then also revealed the role of mediating from thriving at work on the effect of proactive personality on career adaptability. Overall, this study contributes to the literature discussing internet freelance.
\end{abstract}

Keyword: Proactive Personality, Thriving at Work, Career Adaptability, Mediation, Internet Freelance

\section{Pendahuluan \\ Latar Belakang}

Peran career adaptability pada saat ini sangat penting (Chan et al., 2016), karena telah diketahui bahwa pola karir saat ini sudah tidak terbaca dengan jelas yang mana disebabkan sudah terlalu banyak perubahan yang telah terjadi pada dunia pekerjaan, khususnya adalah hubungan kerja antara karyawan dan atasannya serta muncul berbagai model bisnis yang mana membuatnya menjadi semakin tidak berbatas dan transparan, salah satu contohnya adalah munculnya $e$ - lancing yang melihat upaya dari freelance atau pekerja lepas dimana mereka bergerak untuk mencari pekerjaan melalui internet atau dengan kata lain melalui online (Aguinis \& Lawal, 2013; Jiang, 2017; Ren et al., 2015).

Career adaptability sendiri dianggap sebagai sebuah kemampuan individu untuk melakukan penyesuaian terhadap perubahan terkait dengan karir, integrase dengan lingkungan serta keberhasilan individu di setiap peralihan dari rentang fase karir ( growth, exploration, establishment, maintenance, disengagement) seseorang (Savickas, 1997; Savickas \& Porfeli, 
2012). Career adaptability dilihat juga sebagai sebuah sumber daya psikososial (penggambaran hubungan antara kondisi social dengan kesehatan mental seseorang) yang dapat mengarahkan individu pada fungsi dirinya terhadap konteks pekerjaan dan didefinisikan sebagai sebuah sikap, kompetensi, serta perilaku yang digunakan individu untuk dapat menyesuaikan dirinya pada pekerjaan yang sesuai dengan mereka (Chan et al., 2016; Haibo et al., 2018; Jiang, 2017; Tolentino et al., 2014).

Berdasarkan pengertian dan argument terkait dengan career adaptability, maka dapat dikatakan bahwa konsep tersebut dapat membantu individu untuk mengevaluasi kemampuannya karena secara tidak langsung dapat dikatakan bahwa career adaptability mencerminkan kemampuan individu untuk mempersiapkan diri mereka dalam menanggapi perubahan di masa yang akan datang (Chan et al., 2016). Adaptasi yang berhasil dapat terjadi apabila individu memiliki keinginan (adaptivity) dan mampu (adaptability) menanggapi berbagai situasi dengan perilaku yang sesuai untuk situasi tersebut, sehingga dapat dipahami bahwa adaptivity merupakan sebuah komponen sifat yang mana dianggap sebagai sebuah kecenderungan dalam penguasaan diri dan dioperasionalkan salah satunya sebagai proactive personality (Tolentino et al., 2014).

Proactive personality sendiri merupakan sebuah kecenderungan individu yang mengarah pada perilaku proaktif dan dapat memberikan pengaruh pada perubahan yang berarti di lingkungannya, sehingga dianggap sebagai sebuah factor penting yang dapat memengaruhi bentuk dari career adaptability (Cai et al., 2015; Jiang, 2017; Tolentino et al., 2014). Berdasarkan pengertiannya, proactive personality akan membuat individu untuk menjelajahi kesempatan, menunjukan inisiatif, mengambil tindakan dan juga berusaha sekeras mungkin untuk dapat mencapai sebuah tujuan yang diinginkannya serta memiliki pengaruh yang membuat lingkungannya menjadi berubah (Wang et al., 2014). Dalam mendukung pendapat sebelumnya, Jiang (2017) berpendapat bahwa individu yang proaktif memiliki kemungkinan yang lebih besar untuk memiliki persiapan yang lebih baik dalam menghadapi perubahan sehingga membuat perubahan tersebut relevan dengan keterampilannya yang mana akan memberikan mereka kecenderungan untuk merasakan dan kemudian bertindak pada kesempatan karir serta menciptakan lingkungan pekerjaan yang sesuai dengan ketertarikannya.

Memang telah banyak ditemukan dari berbagai literature yang membahas mengenai hubungan antara proactive personality dan career adaptability (Cai et al., 2015; Haibo et al., 2018; Jiang, 2017; Tolentino et al., 2014) dan semua literature tersebut menunjukan hubungan positif yang signifikan, namun telah dinyatakan oleh Jiang (2017) bahwa mekanisme yang mendasari hubungan tersebut masihlah belum jelas, sehingga muncul sebuah usulan untuk membahas mengenai peran mediasi yang dimoderasi. Penelitian ini tidak membahas mengenai peran moderasi karena focus penelitian ini adalah untuk mengungkap peran dari thriving at work sebagai mediator pada pengaruh dari proactive personality terhadap career adaptability yang mana akan diperdalam secara konseptual maupun metode penelitiannya.

Thriving at work sendiri dianggap sebagai sebuah keadaan psikologis, dimana individu mengalami dua buah perasaan, yaitu learning dan vitality secara bersamaan (Jiang, 2017; Prem et al., 2017; Ren et al., 2015; Simone, 2016; Spreitzer et al, 2005). Berdasarkan definisinya, dapat dikatakan bahwa thriving at work merupakan sebuah keadaan psikologis yang mana dapat melanjutkan pengaruh dari proactive personality kepada career adaptability, karena kesuksesan dan pengembangan yang berkelanjutan dari adaptability resource pada perjalanan karir seseorang yang mungkin diarahkan oleh orientasi daya tahan individu terkait dengan 
energy, vitality, dan learning yang kemudian juga telah diketahui sebagian besar bahwa hal tersebut dapat dikembangkan dari eksplorasi proaktif individu (Jiang, 2017).

Model yang membahas thriving at work dibangun dari self-determination theory, dimana teori tersebut menjelaskan dari sisi kondisi social untuk mendorong pengembangan dari jenis motivasi seseorang berdasarkan competence, autonomy, dan relatedness (Deci \& Ryan, 2015; Ren et al., 2015; Spreitzer et al., 2005), yang pada model thriving at work, ketiga kebutuhan psikologis dasar manusia menjadi kunci utama dalam menjelaskan unit contextual feature (decision-making discretion, broad information sharing, climate of trust and respect) (Spreitzer et al., 2005).

Seperti yang sudah disinggung sebelumnya pada awal bab ini, penulis mengatakan bahwa muncul sebuah pengaturan pekerjaan baru atau hubungan antara pekerja dan atasannya pada abad 21 saat ini, yang disebut sebagai E-lancing atau internet freelancing. Istilah $E$ lancing (Aguinis \& Lawal, 2013) dianggap sebagai sebuah marketplace, yaitu sebuah website dimana individu tertarik untuk dapat dipekerjakan dan pada saat yang bersamaan terdapat perusahaan, organisasi, atau bahkan individu yang mencari pekerja (karyawan) yang dapat digunakan jasanya untuk menyelesaikan tugas miliknya.

Freelance sendiri dikatakan sebagai seorang professional yang terampil dan dapat menyediakan jasa dari seorang ahli sehingga mereka dilihat sebagai pengusaha atau dianggap sebagai smallest of small business dibandingkan sebagai pekerja (Kuhn, 2016). Berbeda dengan apa yang disebutkan oleh literatur lainnya yang mana menyatakan bahwa internet freelance pada sebuah platform dianggap sebagai seorang pekerja daripada penjual atau penyedia jasa, karena perusahaan platform yang menjadi pihak ketiga tersebut memiliki kuasa untuk menciptakan pilihan operasional yang menentukan bagaimana control dialokasikan diantara pekerja, klien dan perusahaan (Kuhn \& Maleki, 2017).

Pada akhirnya penulis pada saat ini beranggapan sesuai dengan literatur yang mengatakan bahwa freelance dari sebuah platform atau marketplace yang dimaksud sebagai seorang pekerja. Hubungan pekerjaan seperti internet freelance semakin penting untuk dibahas dan menanggapinya sebagai sebuah kesempatan yang unik bagi literatur HRM, OB, dan I/O Psikologis dalam mempelajari topik yang sangat penting bagi organisasi dan masyarakat (Aguinis \& Lawal, 2013). Penting bagi masyarakat dan organisasi karena terdapat data yang berdasarkan literatur (Burke et al., 2019) menyatakan bahwa pekerja yang terlibat dengan hubungan pekerjaan alternative (seperti freelance) meningkat dari 10.1 persen dari jumlah semua pekerja pada tahun 2005 menjadi 15.8 persen pada tahun 2015, yang kemudian didukung pula oleh pernyataan yang mengatakan bahwa penting untuk mempelajari topik ini disebabkan karena topik ini menawarkan jutaan pengguna dan juga miliaran dollar dalam transaksi (Aguinis \& Lawal, 2013), dimana hal tersebut sesuai dengan keadaan ketenagakerjaan di Indonesia yang mana memiliki jutaan pekerja bebas pada sector pertanian maupun non-pertanian.

\section{Rumusan Masalah}

1. Apakah Proactive personality memiliki pengaruh positif signifikan terhadap career adaptability?

2. Apakah proactive personality memiliki pengaruh positif signifikan terhadap thriving at work?

3. Apakah thriving at work memiliki pengaruh positif siginifikan terhadap career adaptability? 
4. Apakah thriving at work memediasi pengaruh antara proactive personality pada career adaptability?

\section{Tinjauan Pustaka \\ Thriving at Work}

Konsep dan model yang menjelaskan mengenai thriving at work muncul pertama kali ketika diperkenalkan oleh Spreitzer et al (2005), yang seringkali thriving at work didefinisikan sebagai sebuah keadaan psikologis dari seseorang yang mengalami dua buah perasaan secara bersamaan, yaitu sense of learning - mengacu pada pemahaman individu yang lebih baik lagi, dan sense of vitality - mengacu pada gairah dan semangat untuk melakukan pekerjaan (Abid et al., 2018; Burke et al., 2019; Jiang, 2017; Jiang et al., 2019; Nawaz et al., 2018; Paterson et al., 2014; Porath et al., 2012; Prem et al., 2017; Sia \& Duari, 2018; Spreitzer et al., 2005).

Berdasarkan definisinya, thriving at work yang dilihat sebagai sebuah keadaan psikologis seseorang maka masuk akal jika dikatakan bahwa thriving at work bersifat sementara (Spreitzer et al., 2005), dan berdasarkan literatur yang sama juga telah dinyatakan bahwa kondisi psikologis tersebut membantu setiap individu untuk memiliki pemahaman yang lebih baik mengenai salah satu ujung positif dari spektrum yang terkait dengan pengalaman karyawan di tempat kerja. Thriving at work dapat digunakan sebagai sebuah tolak ukur, karena pengalaman subyektif yang dirasakan oleh individu tersebut dapat mengukur apakah yang individu lakukan dan bagaimana mereka melakukannya dapat membantu dalam mengembangkan dirinya ke arah positif (Jiang, 2017).

Pada model yang diajukan oleh Spreitzer et al (2005), telah dinyatakan bahwa agentic work behavior adalah salah satu antaseden dari thrivinig at work, dimana ketika individu berada pada kategori agentic work behavior maka mereka akan bertindak secara agen dan cenderung untuk mengalami sense of vitality dan sense of learning, kemudian pendapat tersebut dilengkapi oleh Bandura (2001), dimana individu yang bertindak secara agen adalah ketika individu tersebut aktif dan memiliki tujuan dalam pekerjaannya (Spreitzer et al., 2005).

Agentic work behavior yang dibahas pada model thriving at work sendiri adalah perilaku agen yang memiliki kontribusi terhadap thriving at work, yaitu adalah task focus yang menggambarkan sejauh mana individu memfokuskan perilaku mereka dalam memenuhi tanggung jawab yang ditugaskan di tempat kerja sehingga mereka dapat menyelesaikan tugas yang diberikan dengan baik dan dapat memuaskan pemberi tugas tersebut, kemudian exploration - yang mengacu pada keterlibatan dari perilaku eksperimental, pengambilan resiko, penemuan, dan inovasi yang dapat membantu individu untuk berkembang dan tumbuh kearah yang baru, selanjutnya adalah agentic work behavior yang terakhir, yaitu adalah heedful relating - diartikan sebagai sebuah perilaku penuh perhatian pada lingkungan sekitarnya sehingga dapat dikatakan bahwa setiap karyawan saling memperhatikan dengan kesatuan niat, yaitu adalah berfungsinya system dengan cara yang efektif (Sia \& Duari, 2018; Spreitzer et al., 2005).

Menurut Spreitzer et al (2005), Agentic work behavior pun dapat terjadi ketika individu terikat pada unit contextual feature dengan mendorong decision making discreation, broad information sharing, dan climate of trust and respect sehingga individu tersebut akan cenderung menanggapinya dengan agentic work behavior yang akan mendorong individu untuk mengalami thriving at work. Ketika individu memiliki agentic work behavior maka mereka menghasilkan serangkaian resource produced in the doing of work yang akan memberikan umpan balik dimasa yang akan datang untuk mendorong agentic work behavior 
sehingga dapat mencapai thriving at work, maka dapat disimpulkan setelah lingkungan sosialnya memberikan pemenuhan atas unit contextual feature yang dibutuhkannya, hal tersebut akan mendorong agentic work behavior yang akan menciptakan resource produced in the doing of work dan akan memberikan umpan balik kepada agentic work behavior sehingga dapat mencapai thriving at work (Burke et al., 2019; Spreitzer et al., 2005; Porath et al., 2012).

Terkait dengan unit contextual feature, telah dinyatakan bahwa hal tersebut merupakan bagian dari model thriving at work yang dibangun berdasarkan self determination theory (SDT), dan SDT sendiri dianggap sebagai sebuah kunci untuk menjelaskan mekanisme bagaimana konteks terkait dapat memungkinkan terjadinya agentic work behavior, karena SDT sendiri mendeskripsikan bagaimana individu mengejar kondisi yang memperkuat pertumbuhan dan perkembangan dirinya (Ren et al., 2015; Spreitzer et al., 2005). SDT dianggap sebagai landasan terbentuknya thriving at work yang terkait dengan sosial karena terdapat tiga kebutuhan dasar psikologis seseorang yang perlu dipenuhi berkaitan dengan autonomy, competence, dan relatedness, yang mana ketika kebutuhan dasar psikologis tersebut terpenuhi maka individu memiliki kecenderungan untuk mencapai keadaan yang dikenal sebagai thriving at work (Ren et al., 2015).

Berkaitan dengan model yang diajukan oleh Spreitzer et al (2005), telah dinyatakan sebagai sebuah intrinsic motivation atau dapat dikatakan masuk kedalam kategori autonomous motivation daripada masuk kedalam kategori controlled motivation atau amotivation, hal ini disebabkan apabila individu tidak terikat secara intrinsik dari motivasinya, maka individu tersebut tidak akan merasakan thriving at work dalam pekerjaannya, karena secara logika dapat dikatakan bahwa apabila tidak termotivasi secara internal, maka individu yang bersangkutan merasa terpaksa atau telah dikontrol oleh atasan atau bahkan kondisi pekerjaannya, dan untuk mencapai keadaan dimana individu masuk kedalam kategori autonomous motivation maka ketiga kebutuhan psikologis dasar dari manusia seperti autonomy, competence, dan relatedness harus terpenuhi (Gagné \& Deci, 2005).

Kondisi psikologis yang dikenal sebagai thriving at work juga seringkali dikaitkan dengan general health, karena ketika individu merasakan vitality yang mencerminkan gairah dan semangat untuk bekerja serta hidup, maka individu tersebut akan memiliki kemungkinan yang lebih kecil untuk merasakan anxious dan depressed sehingga menciptakan kesehaatan mental yang lebih baik, kemudian diketahui juga bahwa ketika individu merasakan learning pada pekerjaan, maka individu tersebut akan memiliki kemungkinan yang lebih tinggi untuk mengkontribusikan secara positif terhadap kesehatan mental dan juga fisiknya (Spreitzer et al., 2005).

Thriving at work dinyatakan sebagai sebuah konsep yang sangat penting untuk diperhatikan pada diri seseorang dan dibahas secara empiris yang mana terkait dengan lingkungan pekerjaannya, karena individu secara konsisten dituntut untuk dapat belajar dalam mengatur arah perubahan pada karirnya (Ren et al., 2015), dan pada saat ini setiap organisasi dituntut untuk memberikan perhatian khusus pada tenaga kerjanya yang dapat mencapai kondisi psikologis yang dikenal sebagai thriving at work, karena tenaga kerja tersebut memiliki energi untuk bertumbuh dan berkembang yang mana akan memberikan kontribusi positif terhadap perusahaan atau organisasinya (Prem et al., 2017).

\section{Proactive Personality}

Pada saat ini individu dituntut untuk menjadi seorang agen yang aktif, karena mereka dituntut untuk dapat berinteraksi dengan lingkungannya, berhadapan dengan peralihan 
pekerjaan dan trauma, serta juga dituntut untuk mengatasi tantangan yang dapat diantisipasi namun tidak terduga (Cai et al., 2015). Pernyataan tersebut mengarahkan penulis pada konsep dari proactive personality, karena dinyatakan oleh berbagai literatur (Bateman \& Crant, 1993, 2000 ; Cai et al., 2015; Jiang, 2017; Tolentino et al., 2014; Wang, 2014; Zhang et al., 2018) bahwa proactive personality merupakan sebuah kepribadian seseorang yang secara relative tidak dibatasi oleh berbagai kondisi dan dianggap sebagai individu yang dapat memengaruhi lingkungannya dengan melakukan perubahan.

Wang et al (2014) menyatakan bahwa individu dengan proactive personality yang tinggi dapat menemukan kesempatan untuk bertumbuh dengan sendirinya dan juga secara aktif mengejar perubahan yang akan menguntungkan bagi pengembangan diri mereka, sehingga mereka memiliki kemungkinan akan menggunakan berbagai pendekatan untuk membatasi ancaman yang ada, namun berbeda dengan individu yang memiliki proactive personality rendah, dimana individu pada tingkatan proaktif yang rendah akan lebih memiliki keterbatasan untuk memengaruhi keadaan mereka. Sejalan dengan personal agency perspective yang telah disoroti oleh career-construction theory menyatakan bahwa focus dari proaktif menyiratkan individu dapat memberlakukan perubahan untuk memperbaiki lingkungan mereka dan tidak secara pasif bereaksi terhadap kendala yang ada dilingkungannya (Jiang, 2017).

Telah diketahui pula bahwa dasar - dasar teoritis dari proactive personality berlabuh pada kapasitas dalam mengatur drinya sendiri untuk merespons dan berupaya agar dirinya dapat berhasil dalam menyesuaikan keadaan pada kehidupannya, sehingga individu tersebut dapat mendorong dirinya untuk lebih terbiasa dengan lingkungan, dan seringkali terlibat dalam pembelajaran secara aktif, serta dapat menempatkan dirinya dalam situasi dimana mereka mengalami perkembangan (Tolentino et al., 2014).

Proactive personality juga dinyatakan dapat mengurangi ketidakpastiaan lebih cepat karena memiliki tiga gagasan atribut dari proaktif, yaitu change orientation - ketika individu berupaya untuk merubah proses yang ada, self initiation - ketika individu melakukan sebuah tindakan, dan future focus - ketika individu memikirkan berbagai cara untuk mencapai masa depan yang diinginkan (Parker et al., 2010). Maka dapat dikatakan bahwa individu dengan proactive personality yang lebih tinggi akan memiliki kecenderungan alami yang memungkinkan individu tersebut untuk melakukan inisiasi dalam penjelajajahan, perencanaan, dan kendali pada peristiwa yang terkait dengan ketidakpastian sehingga dapat meminimalisir ketidakpastiaan tersebut (Jiang, 2017).

\section{Career Adaptability}

Career adaptability dianggap sebagai sebuah sumber daya psikososial (yaitu penggambaran hubungan antara kondisi social seseorang dengan kesehatan mental) yang menandakan kemampuan dan kesiapan untuk mengelola tugas, peralihan, serta trauma yang ada pada saat ini dalam peran pekerjaan individu (Chan et al., 2016; Haibo et al., 2018; Jiang, 2017). Career adaptability diketahui memiliki konstruk yang terdiri dari empat bagian yaitu adalah career concern - berfokus pada karir dirinya dimasa yang akan datang, career control - berforkus pada perasan memiliki dan bertanggung jawab yang dapat mempengaruhi karir individu yang bersangkutan, career curiousity - berfokus pada ketertarikan untuk menjelajahi potensi diri dan peluang karir yang ada, dan terakhir adalah career confidance - berfokus untuk mengejar aspirasi karir dan mengantisipasi hambatan dalam mencapai kesuksesan, dimana keempat konstruk yang dijelaskan sebelumnya digunakan untuk memfasilitasi individu dalam persiapannya menghadapi perubahan karir pada saat ini dan masa yang akan datang, sehingga 
dapat dikatakan bahwa career adaptability yang memiliki empat inti didalamnya memungkinkan penyesuaian pada diri individu yang berhubungan dengan karir, penyatuan dengan lingkungan, serta keberhasilan melakukan peralihan di seluruh masa karir yang dialami oleh individu terkait (Chan et al., 2016; Haibo et al., 2018; Jiang, 2017; Tolentino et al., 2014).

Career adaptability dianggap sebagai sebuah bentuk dari sumber daya yang penting serta dilihat sebagai factor yang mendorong individu dalam mencapai tujuan pekerjaan, maka dari itu career adaptability memungkinkan individu untuk mengambil tanggung jawab pribadi bagi kepentingan pengembangan dan lingkungan kerja mereka dengan menunjukan displin diri, sehingga diasumsikan apabila individu memiliki career adaptability dengan tingkatan yang lebih tinggi maka mereka akan memiliki lebih banyak kompetensi dan motivasi pada tugas pekerjaan saat ini dan masa yang akan datang (Haibo et al., 2018).

Career adaptability merupakan konsep inti yang tertanam pada career construction theory, dimana teori tersebut melibatkan kesiapan individu untuk mengatasi tugas yang dapat diprediksi dengan melakukan persiapan dan berpartisipasi pada pekerjaan serta melakukan penyesuaian yang tak terduga akibat perubahan pekerjaan serta kondisinya, sehingga career adaptability diketahui sebagai salah satu konstruk psikologis yang mencerminkan sumberdaya individu dalam mengatur dirinya untuk dapat mengatasi beragam situasi dan kondisi pada tugas pengembangan keterampilan yang merubah integrasi sosial mereka (Jiang, 2017). Peneliti sebelumnya yang berkontribusi pada literatur career adaptability (Cai et al., 2015a; Chan et al., 2016; Haibo et al., 2018; Hou et al., 2012; Jiang, 2017; Tolentino et al., 2014) mendefinisikan career adaptability sebagai sebuah sikap, kompetensi, dan perilaku dimana individu menggunakannya untuk menyesuaikan dirinya pada pekerjaan yang sesuai dengan diri mereka.

\section{Hipotesis}

Hipotesis 1: Proactive personality berpengaruh positif terhadap career adaptability

Hipotesis 2: $\quad$ Proactive personality berpengaruh positif terhadap thriving at work

Hipotesis 3: Thriving at work berpengaruh positif terhadap career adaptability

Hipotesis 4: Thriving at work memediasi pengaruh proactive personality terhadap career adaptability

\section{Metode Penelitian \\ Pendekatan Penelitian}

Penelitian ini masuk kedalam kategori causal comparative, karena dinyatakan oleh Carrie (1996) bahwa penelitian dengan kategori tersebut merupakan penelitian yang menjelaskan mengenai pengaruh dari variable independent pada variable dependent, sehingga penelitian dengan kategori causal comparative dapat menghasilkan pengetahuan mengenai pengaruh antar variable yang berguna untuk menciptakan intervensi pada hasil penelitian. Pada penelitian ini, penulis menggunakan teknik pengumpulan data berupa survey dan dilakukan dengan metode cross-sectional yaitu adalah pengambilan data yang hanya dilakukan pada satu waktu tertentu (Cooper \& Schindler, 2001).

\section{Prosedur Pengumpulan Data}

Data yang dikumpulkan pada penelitian ini adalah data primer, yaitu adalah data yang didapatkan penulis secara langsung (tangan pertama) dan karena penelitian ini adalah 
penelitian kuantitatif, maka penulis menggunakan metode pengumpulan data berupa angket atau biasa dikenal sebagai kuisioner yang berbentuk self report dimana menggunakan pendekatan online (Sekaran, 2006). Penelitian yang menggunakan pendekatan online telah diterapkan pada beberapa penelitian lainnya dan telah dinyatakan sebagai suatu cara yang dapat diandalkan (Jiang, 2017).

\section{Teknik Analisis Data}

Tahap ini menunjukan data hasil dari survey yang telah dilakukan akan diolah untuk dapat menjelaskan dan memberikan gambaran utuh pada variable yang dikaji pada penelitian ini, maka sebelum melakukan pengolahan lebih lanjut penulis akan memastikan asumsi klasik data dan kuisioner terlebih dahulu telah terpenuhi. Penulis juga melakukan hypothesis testing, dan dalam melakukan pengujian hipotesis, penelitian ini akan menggunakan alat analisis yang dikenal sebagai IBM SPSS Statistik V.23 yang dikombinasikan dengan Hayes Process Model 4 untuk dapat menjelaskan model yang diajukan oleh penulis dengan menghitung efek tidak langsung secara keseluruhan dan bersyarat (empat syarat yang harus terpenuhi menurut Baron dan Kenny (1986) untuk menetapkan sebuah variable sebagai mediator) untuk jenis model mediasi sehingga menghasilkan data yang lebih akurat dan dapat diandalkan (Jiang, 2017). Teknik analisis data yang akan dilakukan oleh penulis pada penelitian ini antara lain adalah uji realibilitas dan validitas, analisis deskriptif, uji asumsi klasik, uji korelasi, dan uji regresi dilengkapi dengan PROCESS Hayes (2013).

\section{Hasil dan Pembahasan Gambaran Subyek Penelitian}

Subyek pada penelitian ini memiliki kecenderungan bahwa jumlah pria lebih banyak yang ditunjukan dengan jumlah presentase yaitu sebesar $68.2 \%$ dari jumlah perempuan yang hanya sebesar $31.8 \%$ dari total responden, yaitu 362 individu. Telah diketahui pula bahwa mayoritas usia responden berada pada kisaran 18 sampai dengan 25 tahun atau sebesar $63.3 \%$ dari keseluruhan responden. Tingkat pendidikan dengan presentasi tertinggi adalah SMA sederajat yaitu sebanyak $47.8 \%$, yang kemudian disusul oleh para internet freelance yang telah melalui pendidikan Sarjana sebanyak 39.5\% dan diploma sebanyak 10.8\%. Menurut data yang didapatkan, telah diketahui juga bahwa $80.9 \%$ internet freelance yang menanggapi kuisioner pada penelitian ini belum genap 1 tahun bekerja sebagai internet freelance dan sebanyak $28.2 \%$ bergerak pada bidang pekerjaan administrasi (Entri Data) dengan rata - rata pendapatan perbulan kurang dari 1 juta dengan presentasi sebesar $75.7 \%$ internet freelance.

\section{Uji Regresi Sederhana}

Uji regresi linear sederhana merupakan salah satu teknik analisis statistik yang digunakan untuk memprediksi masa depan berdasarkan nilai dari variable predictor atau independent yang akan berdampak pada variable kriteria atau dikenal sebagai variable dependent (Field, 2013), dengan kata lain analisis regresi adalah mengenai aktivitas meramalkan masa depan (yang tidak diketahui) berdasarkan data yang telah dikumpulkan dari masa lalu (yang telah diketahui) (Griffith, 2009). Uji ini dilakukan untuk mengetahui hubungan setiap variable yang ada pada penelitian ini, yaitu proactive personality, thriving at work, dan career adaptability. Pada penelitian ini melakukan regresi pada beberapa model dari analisis regresi sederhana untuk mengetahui peranan dari mediasi yang mana diperankan oleh thriving at work pada hubungan dari proactive personality terhadap career adaptability. 
Tabel 1. Hasil Regresi Linear Sederhana Proactive Personality Terhadap Career Adaptability (Model I)

\section{Coefficients $^{\mathrm{a}}$}

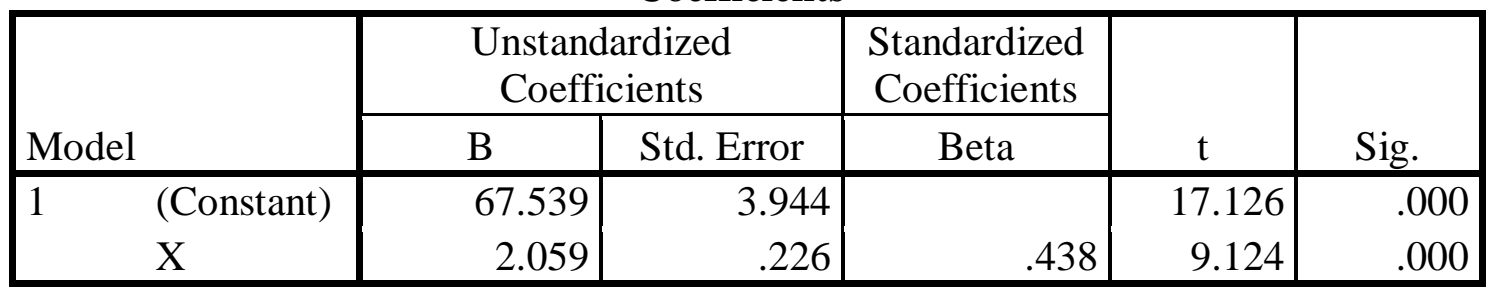

a. Dependent Variable: $\mathrm{Y}$

b. $\mathrm{R}=.438$ dan $\mathrm{R}^{2}=.192$

Berdasarkan hasil regresi variable $\mathrm{x}$ (proactive personality) terhadap variable y (career adaptability), dimana hubungan variable $\mathrm{x}$ ke y diasumsikan oleh penulis sebagai jalur c yang mana didapatkan nilai koefisien sebesar $(b$-value $) 2.059(\beta \mathrm{c}=.438)$, dengan tc $=9.124$ dan signifikansi $p \leq .05$, maka dengan demikian dapat dikatakan bahwa proactive personality secara signifikan memengaruhi career adaptability, atau dengan kata lain syarat pertama yang diajukan oleh Baron dan Kenny (1986) telah terpenuhi sehingga H1 di dukung.

Tabel 2. Hasil Regresi Linear Sederhana Proactive Personality Terhadap Thriving at Work (Model II)

\section{Coefficients $^{\mathrm{a}}$}

\begin{tabular}{|c|c|c|c|c|c|}
\hline \multirow[b]{2}{*}{ Model } & \multicolumn{2}{|c|}{$\begin{array}{c}\text { Unstandardized } \\
\text { Coefficients }\end{array}$} & \multirow{2}{*}{\begin{tabular}{|c|}
$\begin{array}{c}\text { Standardized } \\
\text { Coefficients }\end{array}$ \\
Beta \\
\end{tabular}} & \multirow[b]{2}{*}{$\mathrm{t}$} & \multirow[b]{2}{*}{ Sig. } \\
\hline & $\mathrm{B}$ & Std. Error & & & \\
\hline (Constant) & 22.807 & 2.128 & & 10.717 & .000 \\
\hline X & 1.070 & .122 & .425 & 8.781 & .000 \\
\hline
\end{tabular}

Berdasarkan hasil regresi variable $\mathrm{x}$ (proactive personality) terhadap variable $\mathrm{z}$ (thriving at work), dimana hubungan variable $\mathrm{x}$ ke $\mathrm{z}$ diasumsikan oleh penulis sebagai jalur a yang mana didapatkanlah nilai koefisien sebesar $(b$-value $) 1.070(\beta \mathrm{a}=.425)$, dengan ta $=8.781$ dan signifikansi $p \leq .05$, sehingga dapat dikatakan bahwa proactive personality secara signifikan memengaruhi thriving at work, atau dengan kata lain syarat kedua yang diajukan oleh Baron dan Kenny (1986) telah terpenuhi sehingga H1 didukung.

Tabel 3. Hasil Regresi Linear Sederhana Proactive Personality Terhadap Career Adaptability Melalui Thriving at Work (Model III)

\begin{tabular}{|c|c|c|c|c|c|c|}
\hline \multicolumn{7}{|c|}{ Coefficients $^{\mathrm{a}}$} \\
\hline \multirow{2}{*}{\multicolumn{2}{|c|}{ Model }} & \multicolumn{2}{|c|}{ Unstandardized Coefficients } & $\begin{array}{l}\text { Standardized } \\
\text { Coefficients }\end{array}$ & \multirow[b]{2}{*}{$\mathrm{t}$} & \multirow[b]{2}{*}{ Sig. } \\
\hline & & $\mathrm{B}$ & Std. Error & Beta & & \\
\hline 1 & (Constant) & 46.111 & 3.923 & & 11.754 & .000 \\
\hline & X & 1.054 & .215 & .224 & 4.900 & .000 \\
\hline & Z & .940 & .085 & .503 & 10.989 & .000 \\
\hline
\end{tabular}

a. Dependent Variable: $Y$

b. $\mathrm{R}=.632$ dan $\mathrm{R}^{2}=.400$ 
Berdasarkan hasil regresi variable $\mathrm{z}$ (thriving at work) ke y (career adaptability), hubungan variable $\mathrm{z}$ ke y diasumsikan oleh penulis sebagai jalur $\mathrm{b}$, dan hasil dari table 4.19 telah didapatkan nilai koefisien sebesar $(b$-value $) .940(\beta \mathrm{b}=.503)$, dengan $\mathrm{tb}=10.989$ serta signifikansi $p \leq .05$, sehingga dapat dikatakan bahwa thriving at work memiliki pengaruh terhadap career adaptability.

Berdasarkan table 4.19 diketahui bahwa nilai koefisien ( $b-v a l u e)$ jalur $c$ ' adalah sebesar 1.054, dimana berdasarkan nilai ini telah terjadi penurunan yang cukup signifikan dari jalur c (hubungan antara proactive personality dan career adaptability sebelum peran mediasi muncul) yang nilainya didapatkan sebesar $2.059\left(\beta \mathrm{c}^{\prime}=.224\right)$, tc' $=4.900$ dan signifikansi $p \leq$ .05 , maka apabila dilihat dari hasilnya hubungan antara proactive personality pada jalur c' memang masih signifikan, namun $b$-value pada jalur terkait nilainya menurun sehingga mengindikasikan bahwa terdapat pengaruh atas mediasi yang terjadi pada hubungan tersebut.

Maka dengan hasil yang tertera pada table 4.19, telah diketahui bahwa terdapat peran mediasi dari thriving at work pada hubungan proactive personality dan career adaptability, dimana mediasi yang ada pada penelitian ini adalah berjenis parsial. Mediasi parsial yang diperankan oleh thriving at work terjadi karena terdapat penurunan nilai koefisien $(b-v a l u e)$ ketika muncul variable mediasi pada hubungan tersebut. Berdasarkan hasil uji pada table 4.19, dapat dikatakan bahwa syarat ketiga dan keempat yang telah diajukan oleh Baron dan Kenny (1986) telah terpenuhi pada penelitian ini, sehingga H-3 dan H-4 didukung.

\section{Uji Regresi Menggunakan PROCESS}

Salah satu alternative untuk dapat mengetahui peran mediasi pada sebuah variable dari hubungan antara predictor dan hasilnya adalah menggunakan metode regresi tingkat lanjut yang dikenal sebagai PROCESS HAYES (Field, 2013; Hayes, 2013; Jiang, 2017) yang mana metode ini menggunakan metode bootstrapping untuk menghitung efek tidak langsung, kemudian diketahui juga bahwa metode ini tidak mengalami keterbatasan seperti pada sobel test dan causal effect model, maka dengan kata lain tools yang dikembangkan oleh Hayes (2013) ini memungkinkan setiap individu untuk dapat menghasilkan sebuah output bagi efek tidak langsung (jalur axb), termasuk interval kepercayaan dan effect size (Field, 2013; Hayes, 2013). Pada penelitian ini, penulis telah berhasil menggunakan tools terkait yang mana menghasilkan output yang akan dilampirkan pada akhir skripsi.

Berdasarkan hasil yang didapatkan oleh peneliti dan dipandu interprestasinya melalui literatur yang telah ditulis oleh Field (2013), maka penulis dapat menyimpulkan bahwa hasil yang didapatkan atas penelitian ini menggunakan PROCESS pada IBM SPSS V.23 mengkonfirmasi lebih lanjut hasil dari causal step Baron dan Kenny (1986) yang telah dilakukan oleh penulis pada bagian sebelum ini dengan menggunakan regresi sederhana pada beberapa model. Berdasarkan hasil PROCESS telah terjadi indirect effect (peran mediator) pada hubungan antara proactive personality dan career adaptability melalui thriving at work adalah signifikan ( $b=1.0048$, BCa CI [.7337, 1.3029), apabila dijabarkan maka dapat dikatakan bahwa nilai efek tidak langsung tidak terstandar bootstrap sebesar 1.0048, dan confidance interval (CI) sebesar $95 \%$ berkisar antara 0.73 sampai 1.30, dan karena nol (0) tidak termasuk kedalam rentang interval kepercayaan 95\%, maka dapat ditarik kesimpulan bahwa terdapat efek tidak langsung yang signifikan antara proactive personality pada career adaptability melalui thriving at work. 


\section{Pembahasan}

Sejalan dengan berbagai literatur yang telah membahas mengenai hubungan antara proactive personality dan career adaptability, penelitian ini dapat dikatakan telah memvalidasi lebih lanjut mengenai dugaan teoritis, dimana atribut dari proactive personality seperti changeoriented, future focus, dan self initiation yang berguna untuk mengurangi ketidakpastian serta meningkatkan lingkungannya agar sesuai dengan keinginannya dapat disejajarkan dengan personal agency focus atau perspective pada career construction theory (Jiang, 2017; Parker et al., 2010; Savickas \& Porfeli, 2012; Tolentino et al., 2014). Untuk memperluas cakupan dari pembahasan hubungan antara proactive personality dan career adaptability, penelitian sebelumnya telah menemukan peran mediasi dari thriving at work dimana berdasarkan variable tersebut dapat mengungkap bagaimana mekanisme atau proses dari proactive personality dapat membentuk career adaptability (Jiang, 2017). Pada penelitian kali ini penulis pun berhasil mengungkap peran mediasi dari thriving at work pada hubungan tersebut dengan subyek baru, yaitu internet freelancer.

Seperti yang telah dikatakan oleh Field (2013) bahwa mediasi mengacu pada sebuah situasi dimana sebuah variable dapat menjelaskan keterkaitan antara variable prediktor dan variable kriteria. Hubungan antara proactive personality dan career adaptability melalui thriving at work pun telah dijelaskan secara konseptual sehingga hal tersebut memenuhi persyaran yang diajukan oleh Field (2013). Lain hal dengan persyaratan yang diajukan Field (2013) tersebut, karena berdasarkan pernyataannya penulis hanya melihat permintaan dari sudut konseptual saja, kemudian penulis pun memandang dari aspek metode dimana Baron dan Kenny (1986) memiliki beberapa kondisi yang harus terpenuhi jika seorang peneliti ingin menetapkan sebuah variable sebagai mediator, yaitu 1) predictor haruslah secara signifikan memprediksi outcome, 2) predictor harus secara signifikan memprediksi mediator, 3) mediator harus secara signifikan memprediksi outcome dan 4) hubungan antara predictor dan outcome harus lebih lemah ketika memasukan mediator kedalam model.

Konsisten dengan hipotesis yang diajukan oleh penulis, dimana $\mathrm{H} 1$ menyatakan bahwa proactive personality berpengaruh positif terhadap career adaptability, sehingga dapat dimaknai bahwa ketika individu yang terlibat pada hubungan pekerjaan sebagai internet freelance dan memiliki kepribadian yang proaktif (proactive personality) maka mereka memiliki kemungkinan untuk dapat membentuk adaptability resource yang kemudian individu tersebut dapat dianggap memiliki kemampuan untuk beradaptasi pada pekerjaan yang sesuai dengan ketertarikannya, dengan kata lain individu yang terlibat pada hubungan pekerjaan sebagai internet freelance tersebut dapat dianggap telah memiliki career adaptability. Maka H1-pun terbukti pada penelitian ini..

Kemudian $\mathrm{H} 2$ yang menyatakan bahwa proactive personality berpengaruh positif terhadap thriving at work, sehingga dapat dimaknai bahwa ketika individu yang terlibat pada hubungan pekerjaan sebagai internet freelance dan memiliki kepribadian proaktif (proactive personality) yang mana didefinisikan sebagai individu yang dapat menemukan kesempatan dan secara aktif mengejar perubahan yang berguna bagi perkembangan dirinya akan lebih mungkin untuk mencapai sebuah kondisi psikologis yang dikenal sebagai thriving at work, karena menurut Jiang (2017) bahwa ketika individu proaktif maka mereka akan lebih mungkin untuk dapat mengalami dua buah perasaan yang membentuk thriving at work, yaitu sense of learning dan sense of vitality. Maka H-2-pun terbukti pada penelitian ini. 
Selanjutnya adalah $\mathrm{H} 3$, yang mana menyatakan bahwa thriving at work berpengaruh positif terhadap career adaptability, sehingga dapat dimaknai bahwa ketika individu yang terlibat pada hubungan pekerjaan sebagai internet freelance dan berada kondisi psikologis yang dikenal sebagai thriving at work maka individu tersebut akan lebih mungkin untuk dapat memiliki sebuah kemampuan untuk dapat beradaptasi pada pekerjaan yang sesuai dengan dirinya atau dikenal sebagai career adaptability.Maka H-3-pun terbukti pada penelitian ini.

Terakhir, H4 menyatakan bahwa thriving at work memediasi hubungan antara proactive personality terhadap career adaptability, sehingga dapat dimaknai bahwa ketika individu yang terlibat dengan hubungan pekerjaan sebagai internet freelance dan memiliki kepribadian proaktif (proactive personality) maka akan lebih mungkin individu tersebut untuk dapat mencapai kondisi psikologis dimana mereka telah mengalami perasaan terkait dengan pemahaman yang lebih baik dan juga gairah pada saat melakukan pekerjaannya sehingga individu tersebut akan lebih mungkin untuk dapat membentuk adaptability resource (career confidance, career concern, career curiosity, dan career control) yang mana akan membantu individu untuk dapat memiliki kemampuan untuk beradaptasi pada pekerjaannya (career adaptability). Maka H-4-pun terbukti pada penelitian ini.

Berdasarkan hasil penelitian yang telah dijabarkan, maka temuan ini telah memberikan bukti nyata bahwa individu yang bekerja sebagai internet freelance dan memiliki tingkat proaktif yang tinggi akan lebih mungkin untuk mencapai keadaan psikologis yang dikenal sebagai thriving at work, dan sebagai hasilnya mereka akan menjadi individu yang lebih baik dalam mengembangkan adaptability resource pada konteks pekerjaan dan karir. Mekanisme mediasi yang didasari oleh thriving at work sampai batas tertentu dapat menjelaskan mengapa dan bagaimana dampak dari proactive personality dapat ditularkan untuk bisa memberikan efek terhadap career adaptability (Jiang, 2017).

Penelitian terdahulu (Porath et al., 2012) memiliki sudut pandang dimana proactive personality melibatkan perubahan internal yang konstruktif dan positif sehingga dapat memicu hal yang membuat individu dapat thriving at work (learning dan vitality), kemudian juga dinyatakan bahwa thriving at work menyiratkan orientasi yang berkelanjutan menuju pengembangan karir, sehingga dengan kata lain penulis dapat katakan bahwa dengan melakukan pemeriksaan terhadap peran mediasi thriving at work pada hubungan proactive personality dan career adaptability, hasil penelitian ini dapat menginformasikan penjelasan empiris awal terkait fungsi dari proactive personality dalam proses career adaptability (Jiang, 2017).

\section{Saran}

Hasil pada penelitian ini menjelaskan bagaimana mekanisme atau proses dari sebuah bentuk kepribadian yang dikenal proaktif (proactive personality) dapat memengaruhi secara tidak langsung pada career adaptability melalui thriving at work atau dengan kata lain thriving at work berperan sebagai mediator pada hubungan antara proactive personality terhadap career adaptability. Seperti yang diketahui berdasarkan penjelasan mengenai fenomena yang diangkat pada penelitian ini, career adaptability memiliki peran yang sangat penting pada konteks internet freelance, karena berbagai pekerjaan yang dilakukan oleh internet freelance tersebut sangat membutuhkan sumberdaya yang dapat menjadi factor pendorong untuk mencapai tujuan pekerjaan, sehingga para internet freelance sangat dituntut untuk bisa beradaptasi dengan pekerjaan yang didapatkannya melalui platform ketenagakerjaan online yang ada. 
Penelitian ini menyatakan bahwa penting bagi organisasi untuk mempertimbangkan penilaian terhadap proactive personality dan kondisi psikologis yang dikenal sebagai thriving at work untuk dapat meningkatkan dan memperkaya career adaptability resource (career concern, career confidance, career curiosity, dan career control) dari para internet freelance yang ada di Indonesia. Sebagai contoh, setiap marketplace atau platform ketenagakerjaan online harus mempertimbangkan tingkat dari proactive personality dan thriving at work para internet freelance agar dapat membuat rencana dari program yang sesuai dengan kebutuhan dan dapat dilakukan oleh perusahaan serta estimasi waktu dan juga biaya yang diperlukan untuk bisa meningkatkan career adaptability dari internet freelance yang terdaftar pada database-nya.

Karena sejauh pengetahun penulis, dan sempat terdapat jurnal yang diulas juga oleh penulis mengatakan bahwa penting untuk memperhatikan para internet freelance pada sebuah platform ketenagakerjaan online, karena antara internet freelance dan perusahaan yang menaunginya (dalam kasus ini adalah platform ketenagakerjaan online) tidak memiliki bukti tertulis bahwa terdapat hubungan pekerjaan yang formal antara internet freelance dan juga perusahaan terkait, sehingga menciptakan fleksibilitas dan kebebasan kepada para internet freelance untuk dapat mengeksplor platform ketenagakerjaan lain yang kemudian akan menciptakan sebuah pertanyaan mengenai platform mana yang lebih baik, oleh sebab pertanyaan tersebut, maka akan berpotensi mengurangi jumlah internet freelance pada sebuah platform ketenagakerjaan online.

Maka dari itu penting bagi perusahaan yang menaungi internet freelance untuk menciptakan sebuah program yang sesuai dan dapat meningkatkan career adaptability yang mana diharapkan dapat memberikan dampak baik kepada perusahaan. Karena memang telah diketahui oleh masyarakat bahwa pendapatan atau revenue stream dari platform ketenagakerjaan online tersebut adalah komisi yang diambil berdasarkan kesepakatan kerja antara internet freelance dan juga client yang menggunakan jasanya melalui platform terkait, sehingga terlihat jelas ketergantungan dari para stakeholder pada pengaturan kerja yang baru ini.

\section{Daftar Pustaka}

Aguinis, H., \& Lawal, S. O. (2013). ELancing: A review and research agenda for bridging the science-practice gap. Human Resource Management Review, 23(1), 6-17. https://doi.org/10.1016/j.hrmr.2012.06.003

Cai, Z., Guan, Y., Li, H., Shi, W., Guo, K., Liu, Y., ... Hua, H. (2015). Self-esteem and proactive personality as predictors of future work self and career adaptability: An examination of mediating and moderating processes. Journal of Vocational Behavior, 86, 86-94. https://doi.org/10.1016/j.jvb.2014.10.004

Chan, S. H. J., Mai, X., Kuok, O. M. K., \& Kong, S. H. (2016). The influence of satisfaction and promotability on the relation between career adaptability and turnover intentions. Journal of Vocational Behavior, 92, 167-175. https://doi.org/10.1016/j.jvb.2015.12.003

Cooper, D. R. \& Schindler, P. S. (2001). Business research methods.

Deci, E. L., \& Ryan, R. M. (2015). Self-Determination Theory. In International Encyclopedia of the Social \& Behavioral Sciences: Second Edition. https://doi.org/10.1016/B978-008-097086-8.26036-4

Field, A. (2013). DISCOVERING STATISTICS USING IBM SPSS STATISTICS. In The British Journal of Psychiatry (Vol. 112). https://doi.org/10.1192/bjp.112.483.211-a 
Gagné, M., \& Deci, E. L. (2005). Self-determination theory and work motivation. Journal of Organizational Behavior, 26(4), 331-362. https://doi.org/10.1002/job.322

Griffith, A. (2009). SPSS For Dummies (2nd Edition). In 2nd Edition. https://doi.org/10.1080/10436929908580238

Haibo, Y., Xiaoyu, G., Xiaoming, Z., \& Zhijin, H. (2018). Career Adaptability With or Without Career Identity: How Career Adaptability Leads to Organizational Success and Individual Career Success? Journal of Career Assessment, 26(4), 717-731. https://doi.org/10.1177/1069072717727454

Hayes, A. F. (2013). Introduction to Mediation, Moderation, and Conditional Process Analysis. In The British Journal of Psychiatry (Vol. 714). https://doi.org/10.1192/bjp.111.479.1009-a

Hou, Z. J., Leung, S. A., Li, X., Li, X., \& Xu, H. (2012). Career Adapt-Abilities Scale-China Form: Construction and initial validation. Journal of Vocational Behavior, 80(3), 686691. https://doi.org/10.1016/j.jvb.2012.01.006

Jiang, Z. (2017). Proactive personality and career adaptability: The role of thriving at work. Journal of Vocational Behavior, 98, 85-97. https://doi.org/10.1016/j.jvb.2016.10.003

Kuhn, K. M. (2016). The rise of the "gig economy" and implications for understanding work and workers. Industrial and Organizational Psychology. https://doi.org/10.1017/iop.2015.129

Kuhn, K. M., \& Maleki, A. (2017). Micro-entrepreneurs, Dependent Contractors, and Instaserfs: Understanding Online Labor Platform Workforces. The Academy of Management Perspectives, 31(3), 183-200. https://doi.org/10.5465/amp.2015.0111

Parker, S. K., Bindl, U. K., \& Strauss, K. (2010). Making things happen: A model of proactive motivation. Journal of Management, 36(4), 827-856. https://doi.org/10.1177/0149206310363732

Porath.C, Spreitzer.G, Gibson.C, G. G. . (2012). Thriving at work: Toward its measurement, construct validation, and theoretical refinement. Journal of Organizational Behavior, 30(September 2012), 839-862. https://doi.org/10.1002/job

Prem, R., Ohly, S., Kubicek, B., \& Korunka, C. (2017). Thriving on challenge stressors? Exploring time pressure and learning demands as antecedents of thriving at work. Journal of Organizational Behavior, 38(1), 108-123. https://doi.org/10.1002/job.2115

Ren, H., Yunlu, D. G., Shaffer, M., \& Fodchuk, K. M. (2015). Expatriate success and thriving: The influence of job deprivation and emotional stability. Journal of World Business, 50(1), 69-78. https://doi.org/10.1016/j.jwb.2014.01.007

Savickas, M. L. (1997). Career Adaptability: An Integrative Construct for Life-Span, LifeSpace Theory. The Career Development Quarterly, 45(3), 247-259. https://doi.org/10.1002/j.2161-0045.1997.tb00469.x

Savickas, M. L., \& Porfeli, E. J. (2012). Career Adapt-Abilities Scale: Construction, reliability, and measurement equivalence across 13 countries. Journal of Vocational Behavior, 80(3), 661-673. https://doi.org/10.1016/j.jvb.2012.01.011

Sekaran, Uma. (2006). RESEARCH METHODS FOR BUSINESS.

Sia, S. K., \& Duari, P. (2018). Agentic work behaviour and thriving at work: role of decision making authority. Benchmarking, 25(8), 3225-3237. https://doi.org/10.1108/BIJ-072017-0204

Simone, S. De. (2016). Conceptualizing Wellbeing in the Workplace. Time, 188(9), 12-15. Retrieved from http://search.ebscohost.com/login.aspx?direct=true\&db=aph\&AN=117693428\&site= ehost-live 
Spreitzer, G., Sutcliffe, K., Dutton, J., Sonenshein, S., \& Grant, A. M. (2005). A Socially Embedded Model of Thriving at Work. Organization Science, 16(5), 537-549. https://doi.org/10.1287/orsc. 1050.0153

Tolentino, L. R., Garcia, P. R. J. M., Lu, V. N., Restubog, S. L. D., Bordia, P., \& Plewa, C. (2014). Career adaptation: The relation of adaptability to goal orientation, proactive personality, and career optimism. Journal of Vocational Behavior, 84(1), 39-48. https://doi.org/10.1016/j.jvb.2013.11.004

Wang, Y. H., Hu, C., Hurst, C. S., \& Yang, C. C. (2014). Antecedents and outcomes of career plateaus: The roles of mentoring others and proactive personality. Journal of Vocational Behavior, 85(3), 319-328. https://doi.org/10.1016/j.jvb.2014.08.003 